\title{
Proposing an innovation-based view of the firm
}

Gabriel J. Costello*

Department of Mechanical and Industrial Engineering, Galway-Mayo Institute of Technology, Galway, Ireland

\begin{abstract}
The purpose of this paper is to contribute to the literature on theories of the firm and argues for the importance of an innovationbased view (IBV). In doing so, it examines the incumbent management theories of the firm, resource-based view (RBV), knowledge-based view (KBV) and dynamic capabilities, considering the recent developments in the academic literature and in the nature of the firm. The research approach of abduction (conceiving of theory) proposed by Peirce and described by Van de Ven is used. A conceptual framework that incorporates the growing influence of information and communications technology and open innovation on the characteristics of the firm is developed. The managerial tradition that originated in the scholarship of Edith Penrose is used to develop the framework, as opposed to the lens of economic 'black box' theories.
\end{abstract}

Keywords: theory of the firm; resource-based view; knowledge-based view; dynamic capabilities; Edith Penrose

(C) De Gruyter Poland Sp. z 0.0.

\section{INTRODUCTION}

There continues to be a lively debate in the literature on the nature of the firm and sources of competitive advantage (Klein et al., 2010; Pitelis and Teece, 2009). This conceptual paper argues that current theories of the firm require an extension to an innovation-based view (IBV) due to the growing importance of open innovation to companies and their subsidiaries. This novel theory of the firm is informed by a review of pertinent literature and an examination of recent changes in the nature of the firm. Information and communications technology (ICT) has had a major impact on business and society, resulting in an opening of the firm's boundaries and increasing the digitalisation of organisations. The work is important as it addresses the change in a firm's environment since the original formulation of theories such as the resource-based view (RBV), knowledge-based view (KBV) and dynamic capabilities (ColarelliO'Connor, 2008). The paper builds on the debate regarding the nature and sources of competitive advantage by providing a new perspective to stimulate research in this key area (Barney, 1991; Drucker, 1988; Grant, 1996; Spender, 1996; Teece et al., 1997; Wernerfelt, 1984). The research approach of abduction (conceiving of theory), proposed by Peirce (2010) and described by Van de Ven (2007), is used. The paper contributes to advancing theory by advocating an IBV of the firm, which is conceptualised as an extension of RBV, KBV and dynamic capabilities.

Innovation is now a major focus for organisations, regions and economies, and the subject is increasingly seen as being crucial not only to success but also to survival. According to Brynjolfsson and Saunders (2009), the fundamentals of the world economy indicate that there will be a continuation of innovation 'through the booms and busts of the financial markets and of business investments' (p. ix). As Becerra (2009: 123) points out, innovation 'is the oil of our economic system that keeps it continually running in search for greater value to customers'. However, Wolfe (1994) warned that the abundant growth in innovation literature has made little contribution to the understanding of innovative behaviours in organisations. More recently, Volberda et al. (2013: 1) conclude that while 'innovation is considered central to firms' competitive advantage', the area of management innovation 'remains an under-researched topic'. Traditional conceptualisations of the firm, particularly the KBV, suggest that advantages ensue when firms focus on the acquisition and sharing of knowledge. I argue in this paper for an IBV that emphasises knowledge acquisition, often from external sources, followed by implementation.

Having set the scene, the paper now proceeds as follows. First, a literature review provides an overview of theories of the firm. The paper then argues that a shifting of attention is required from resources and knowledge 
to an open innovation paradigm. The next section outlines the research approach of developing a theory using abduction. The final section proposes a new theoretical perspective: an IBV of the firm, which is conceptualised not as a replacement but as an extension of RBV, KBV and dynamic capabilities.

\section{LITERATURE REVIEW}

This section argues that competitive advantage in the modern business setting stems from a firm's ability to harness and utilise its innovation potential, which is increasingly exercised in an open environment. This view postulates the need to shift attention from resource and knowledge capabilities and focus more on innovation capabilities. Thus, current theories of the firm need to be extended and updated. This literature review provides a summary of the development of managerial views of the firm, namely RBV, KBV and dynamic capabilities. A definition of innovation is proposed based on an examination of antecedent definitions over approximately the past 30 years. The openinnovation model and its consequences for where knowledge now resides are then discussed. Finally, a figure that conceptualises the chronological development of the firm from efficiency to digitalisation is presented.

\section{Theories of the firm}

Theories of the firm are conceptualisations and models of business enterprises, which explain and predict their structures and behaviours (Grant, 1996). 'As a result, there are many theories of the firm which both compete in offering rival explanations of the same phenomena and complement one another in clarifying these different phenomena' (Grant, 1996: 109). The movement away from viewing the firm as a 'black box' is usually traced to the work of Edith Penrose, who focused on the internal resources of a firm, especially with respect to the management and experience it acquires over time (Sautet, 2000). Penrose, working in the 1950s, argued that the growth of a firm is not just a response to market changes but that it also exhibits an internal developmental process (Penrose, 2009). This paper, while respecting economics scholarship, follows the tradition of Penrose, which was further developed in the strategic management literature (Hoskisson et al., 1999). I will broadly refer to this lens as the managerial view of the firm, incorporating the RBV, the KBV and dynamic capabilities. There is an extensive body of literature on theories of the firm, and a detailed review is beyond the scope of this study. What follows is a brief overview of these incumbent theories to support the argument that they require to be supplemented by an IBV considering the significant changes in the nature of the firm driven by the opening of its boundaries chiefly through advances in ICT.

The RBV has been the subject of much academic debate and no little criticism over the past 20 years. It has become one of the most influential and cited theories in the area of management, and it aims to 'explain the internal sources of a firm's sustained competitive advantage (SCA)' (Kraaijenbrink et al., 2010: 2). The RBV perceives the firm as a unique bundle of idiosyncratic resources and capabilities, where the primary task of management is to maximise value through the optimal deployment of existing resources and capabilities, while developing the firm's resource base for the future (Barney, 1991). 'Its central proposition is that if a firm is to achieve a state of SCA, it must acquire and control valuable, rare, inimitable, and non-substitutable (VRIN) resources and capabilities, plus have the organization $(\mathrm{O})$ in place that can absorb and apply them' (Kraaijenbrink et al., 2010: 3, based on Barney 1991). In an early assessment of the theory, Peteraf (1993) concluded that it had a significant capability to elucidate and integrate research in the area of strategic management. However, in a more recent and comprehensive study, Kraaijenbrink et al. (2010) examined RBV critiques and delineated them into eight categories. They concluded that five of these critiques did not threaten the status of RBV, but three of them raised the following serious questions: VRIN/O is neither necessary nor sufficient for SCA; the value of a resource is too indeterminate to provide for useful theory; and the definition of resource is unworkable (Kraaijenbrink et al., 2010: 6). In a conclusion that supports the work of this IBV study, Peteraf (1993) states that this is an area ripe for research and deserves the concentrated efforts of management scholars.

The KBV of a firm is an outgrowth of the RBV of the firm. The KBV would argue that maximising the value derived from the firm's resources is derived from superior knowledge. In the KBV, the firm is conceptualised as an institution for integrating knowledge (Grant, 1996). The KBV posits that knowledge is the most strategically important of the firm's resources. The ability to produce unique or low-cost products and services is due to superior knowledge. With knowledge, firms become more efficient and effective with the use of scarce resources. This view is gaining increasing attention due to the rapid movements towards knowledge-based economies. However, the danger inherent with the concept of organisational knowledge is that the organisational processes through which 
individuals engage in these activities may be obscured, by their viewing the organisation as an entity that creates, stores and deploys knowledge (Coakes, 2000). The organisational processes that integrate knowledge need explication - in particular, research is necessary to understand where knowledge workers turn to for advice, whether internally or across organisational boundaries, and exactly how they access that advice (Wasko and Faraj, 2005). According to Grant (1996), competitive advantage stems from how effective firms are at integrating the specialised knowledge of their members, and he proposes that this effectiveness depends upon efficiency, the scope, and the flexibility of knowledge integration. Grant (1996) further suggests that organisational capability depends more on the integration mechanism than on the specialist knowledge that employees possess; thus, research should focus on the difficulties of coordinating knowledge among individuals instead of producing cooperation. A major argument of this paper is that an IBV addresses these shortcomings.

Another development of RBV and KBV is the theory of 'dynamic capabilities', described by Douma and Schreuder (2008: 207) as 'the capacity of an organization to purposefully create, extend or modify its resource base'. In their seminal paper on the theory, Teece et al. (1997: 516) define dynamic capability as 'the firm's ability to integrate, build, and reconfigure internal and external competences to address rapidly changing environments'. Dynamic capabilities differ from operational capabilities as they are focused on change and, in doing so, alter the resource base of an organisation. Douma and Schreuder (2008: 208) have identified some of the following features of dynamic capabilities: co-specialisation; asset orchestration; tacit knowledge; firm specificity; and isolating mechanisms. However, the following evaluation by Helfat and Peteraf (2009: 92) should be borne in mind: 'As a field of inquiry, it is still in its infancy; the work remains mostly conceptual and focused on foundational level issues, including the definition of the term'. Now, having presented a brief overview of three influential theories of the firm, I examine literature that links knowledge and innovation.

\section{Linking knowledge and innovation}

Theories adhering to the KBV tend to emphasise the ensuing advantages to firms by way of knowledge acquisition and sharing activities. But such an emphasis is deficient. Innovative outcomes can only materialise when knowledge is utilised. In today's digitally enhanced world, acquiring relevant information can potentially be only a few clicks away. Where once the challenge was accessing and sharing information, the main challenge is now the utilisation of acquired knowledge. Hence, I call for an IBV of the firm where the use of knowledge in the form of innovations is the core performance differentiator. A case in point is the study by Whelan et al. (2011) on why companies fail at open innovation. The companies studied had well-developed formal and informal mechanisms to acquire state-of-the-art knowledge from the outside world. However, what they failed to pay attention to is how that knowledge would reach those people in the firm with the skills to utilise it. Very often, valuable knowledge imported into the firm remained in storage, never to be used.

Leonard (1998) links knowledge to innovation and claims that the successful innovators are organisations that build and manage knowledge effectively. They are the most enthusiastic about pursuing knowledge and the most likely to harness the power of innovation. Leonard illustrates the dimensions of the core capabilities along which all organisations must innovate: physical systems, managerial systems, skills and norms of behaviours. She views organisations as sites of learning and information transfer rather than physical sites or financial entities. The workforce of a forward-looking organisation must be able to process and manipulate knowledge, as well as perform particular skills. Top management should encourage creative chaos among disciplines within the organisation and benchmarking with competitors.

Basadur and Gelade (2006: 45) 'argue that 'current concepts of knowledge management and organisational learning are, by themselves, limited in their ability to improve organisational effectiveness'. As a result, they propose a single framework that combines the 'apprehension of knowledge (understanding) with the creative utilisation of such knowledge'. Previous work by Gordon (1956), cited in their paper, had linked learning and inventing as two parts of a continuous process. In this conceptualisation, learning was regarded as the process of gaining knowledge or understanding, while inventing involved using the knowledge or understanding.

Having briefly traced the development of theories of the firm and linking this development to the innovation debate, I now undertake an important but controversial task: defining innovation arising from a review of the topic.

\section{Defining innovation}

Many scholars trace the introduction of innovation into the realm of economic and social change, specifically to Joseph Schumpeter's (1934) seminal work, the 'Theory of Economic Development'. In this work, he classified 
innovation into five categories: new products (or goods); new methods of production (or processes); new sources of supply (or half-manufactured goods); the exploitation of new markets; and new ways to organise business. In Schumpeter's original schema, innovation is accomplished by 'entrepreneurs' who developed new combinations of existing resources (Swedberg, 1991). However, in his later works, he came to regard the large corporation as the innovative engine driving the development of leading economies (Lazonick, 2005). Fagerberg (2005) makes the fundamental distinction between invention and innovation, whereby the former is regarded as the 'first occurrence', while the latter is the 'first attempt to carry it out into practice'. This is in line with Van de Ven's (1986) assertion that 'an invention or creative idea does not become an innovation until it is implemented or institutionalised'.

Zaltman et al.'s (1973) contingency theory of innovation predicts that the effect of structural variables will be conditional on the two main subdivisions of the innovation process: the initiation stage and the implementation stage. According to these authors, the most important contribution by James Wilson as part of his theoretical work on innovation in the 1960s was the identification of the innovation dilemma, which organisations face during the process of innovation. Wilson (1966) had concluded that it is easier to initiate than implement innovations since organisations can quickly increase capacity to generate new proposals but find it much more difficult to match this capacity in the ratification phase. Slappendel (1996), in her review of innovation from an interactive process perspective, identifies the contribution of Walton (1987), who proposed a framework that emphasised the interaction of individual, organisational and environmental features. Walton acknowledges his debt to the work of Pettigrew (1987), who argued that change should be analysed in terms of the dynamic interplay among context, content and process, with the preferred research approach being one that involved longitudinal case studies.

There is almost universal agreement that innovation is a complex phenomenon to understand and manage (Allen, 2004; Eppinger, 2001; Goffin and Mitchell, 2005; Katz, 2004; OECD, 2005; Poole and Van de Ven, 2000; Rothwell, 1994), while Storey (2004) points out that debate on the very meaning of the term has been controversial and problematical. Table 1 summarises some important contributions to innovation studies described in this section.

Table 1. Some important contributions to innovation studies

\begin{tabular}{|c|c|c|}
\hline Date & Source & Contribution \\
\hline $1930 s$ & Schumpeter & Introduced the concept to social studies \\
\hline $1960 s$ & Wilson & The innovation dilemma \\
\hline $1970 s$ & Zaltman et al. & Contingency theory \\
\hline $1980 s$ & $\begin{array}{l}\text { Walton } \\
\text { Pettigrew } \\
\text { Van de Ven et al. }\end{array}$ & $\begin{array}{l}\text { Interaction of individual, organisational and environmental features } \\
\text { Interplay among context, content and process } \\
\text { Minnesota studies }\end{array}$ \\
\hline 1990s & Slappendel & Innovation perspectives \\
\hline 2000 s & Fagerberg & Oxford handbook of innovation \\
\hline
\end{tabular}

Now, I develop a definition of innovation from an analysis of antecedent definitions in the literature. One of the main challenges of a review of innovation is the range of definitions from a wide body of work. In their analysis of the terms 'innovation' and 'innovativeness' from 21 empirical studies in the new product development (NPD) literature, Garcia et al. (2002) discovered that 'no less than fifteen constructs and at least 51 distinct scale items' were used, leading to a great deal of ambiguity. In the course of his work, Mclnerney (2004) assembled $>30$ author-centric definitions of innovation from publications since 1960. These were built from previous work by Rahmanseresht (1988) and Zain (1993), with Schumpeter's earlier definition being added in recognition of its significance in innovation studies. A content analysis of these innovation definitions was carried out by converting the author-centric definitions in the literature into a concept-centric format in order to identify the most common concepts and also ones that may require further attention (Webster and Watson, 2002). Additional dimensions were also added to the concept matrix to facilitate the analysis. The concepts were categorised into whether they are an adjective (e.g. new, radical), a noun (e.g. product, market) or a verb (e.g. implementation, adoption). Another objective was to enable a metaanalysis of the table in order to investigate whether the definitions can contribute to the development of theory, e.g. whether they exhibit parsimony or have any theoretical glue (Whetten, 1989) - concepts that are discussed later in the paper. This analysis showed that there are only two references to 'people' and one reference to 'resources' in the definitions. This covers the two major areas of ethics: the role of people and resources in the development and 
implementation of an innovation. The other significant feature is that these two definitions both emanate from the work of Andrew Van de Ven et al. in the 1980s.

In summary, an innovation can be an artefact, idea or practice (Zaltman et al., 1973); it can be an organisation (Schumpeter, 1934) and is capable of being learned (Drucker, 1985). It can also be a computer system (Yin et al., 1977) or an information system (Swanson, 1994). It must be perceived to be new by an individual or unit of adoption (Rogers and Shoemaker, 1971), involves people engaged in transactions with others in an institutionalised context (Van de Ven, 1986), requires the ethical (Costello and Donnellan, 2008) use of resources and knowledge (Angle and Van de Ven, 2000) and is increasingly exercised in an open environment (Chesbrough, 2003, 2006; von Hippel, 2005; von Hippel and von Krogh, 2003). These concepts are now integrated into the following proposed definition for this study.

Definition: An innovation is an artefact, idea, practice, organisation, learning or information system - perceived to be new by the unit of adoption - that involves the ethical use of internal and external knowledge and resources through the interaction of people with others and their environment.

It is worth pointing out that this definition differs from the Schumpeterian tradition by specifically mentioning the use of both external knowledge and resources. Such a major transformation requires an investigation into why external knowledge and resources have recently had a significant impact on the nature and operation of the firm. Consequently, this article now examines how the open innovation literature informs the management perspective within the firm.

\section{Changing business paradigms}

Chesbrough (2003) argues that in many industries, the centralised approach to research and development (R\&D), which he terms closed innovation, has become obsolete. He argues that the closed innovation paradigm must be replaced by open innovation, whereby ideas and knowledge from outside the company are adopted in conjunction with internal processes. The factors influencing this change are the mobility of skilled people, the increasing presence of venture capital, the emergent high-tech start-ups and the significant role of university research. The success of companies such as Cisco and Intel has been attributed to their adoption of this new paradigm. In contrast, many believe that the decrease in Xerox's innovation capacity is due to the company's reliance on a closed R\&D system. Chesbrough argues that embracing external ideas and knowledge will actually multiply the advantage of internal efforts. However, connecting external innovation to internal innovation requires a new business model.

Implementation of the business model can be greatly accelerated by buying and selling intellectual property (IP). However, there always remains the hard work of converting research ideas into products, services and solutions that solve customers' problems. Interestingly, he states that the presence of manufacturing, distribution and brand are assets that help the firm retain some of the value it creates. Figure 1 shows an innovation funnel adapted to illustrate an open innovation model.

Figure 1. Chesbrough's (2003) innovation funnel.

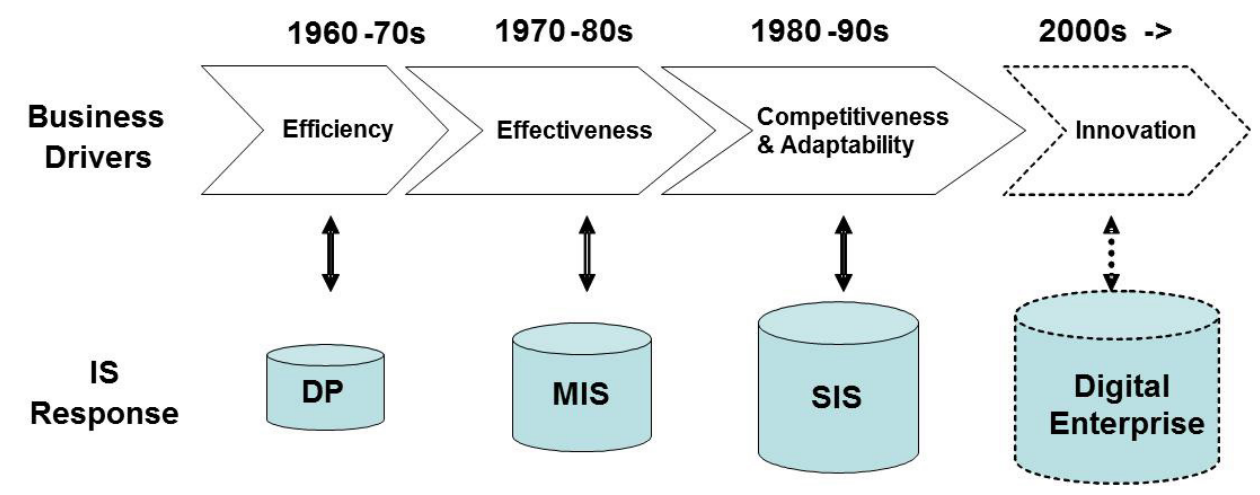


The growing significance of the Open Innovation paradigm (Pullen et al., 2012) has prompted West, Vanhaverbeke and Chesbrough (2006: 288) to propose a research framework with the following classifications: individual, organisational, value network, industry/sector and national institution. In related work, Vanhaverbeke and Cloodt (2006) suggest that emerging forms of value networks must be examined at the level of different nested layers. These diverse layers span the spectrum from the individual to firms-organisations, through Dyads, onto interorganisational networks and, ultimately, reaching to national/regional innovation systems.

In antecedent related research, von Hippel (2005) speaks about the democratisation of innovation, where users of products and services increasingly have the ability to innovate for themselves. This results in a move from manufacturing-centric to user-centric innovation processes. Christensen et al. (2005) note that the old theories of innovation may no longer be relevant to future performance. In their study of the semiconductor industry, they find that Moore's Law is no longer the dominant paradigm for analysing this sector. Customers are less concerned about performance factors, such as clock speed, and are more focused on new parameters such as convenience and customisation. Furthermore, they contend that new, specialised, non-integrated firms will provide a serious threat to the incumbents. One way in which the semiconductor industry can manage these transitions is to adopt disruptiveinnovation and value-migration frameworks. However, it is worth noting that there are some dissenting voices in the context of the rush to a total open innovation model (Birkinshaw et al., 2011), which would suggest that the degree of openness can and should be taken into account. Now, I examine the enormous changes that the revolution in ICT has brought to the firm and its environment.

\section{THE DIGITALISATION OF THE FIRM}

The spectacular growth of the internet, ubiquity of networking, globalisation of business and evolution of information economies has resulted in novel business processes and new ways of sharing knowledge. These transformations are resulting in the development of the fully digital firm (Laudon and Laudon, 2002). Other ICT technologies include mobile computing, teleworking, Web 2.0, social networking and open source, which affect not only business but society as well. ICT has resulted in innovations in the firm, affecting logistics, manufacturing, sales and order management, finance, and human resource management as well as the support activities of design, engineering and marketing (O'Brien and Marakas, 2009; Post and Anderson, 2003). According to Robson (1997: 273), 'quality, innovation and service are now more important than cost, growth and control'. She also goes on to propose the following forces for openness: new technology, new geopolitical order and new enterprises. Furthermore, Robson provides the following taxonomy of the evolution of the firm:

- Efficiency was the price of staying in business in the 1960 s

- Effectiveness was the price of staying in business in the 1970s

- Competitiveness was the price of staying in business in the $1980 \mathrm{~s}$

- Adaptability was the price of staying in business in the 1990s

I argue that

- Innovation is the price of staying in business in the 2000 s

As Pfaffenberger (2002) puts it, 'The internet has emerged as an unparalleled public medium for communication and commerce - and it's changing our world'.

From a management information systems (MIS) perspective, another paradigmatic shift has been the growth and diffusion of self-service technology (SST) (Costello and Donnellan, 2007). An increasing number of business and government transactions are now being completed without human assistance. Consequently, self-service technology and business extends the traditional boundaries of the customer service function.

Figure 2 diagrammatically supports the argument proposed by this paper by building on the three-era model of Ward et al. (1990) and showing the discipline entering a fourth era where the main business driver is innovation.

It should be noted that this figure does not imply that innovation was not an important consideration for enterprises prior to the new millennium. However, ceteris paribus, it is now regarded as the differentiator in an enterprise's success.

Now, I proceed to provide an overview of the research approach adopted in this paper to facilitate the development of theory. 
Figure 2. From a three-era model to a four-era model - developed from Ward et al. (1990).

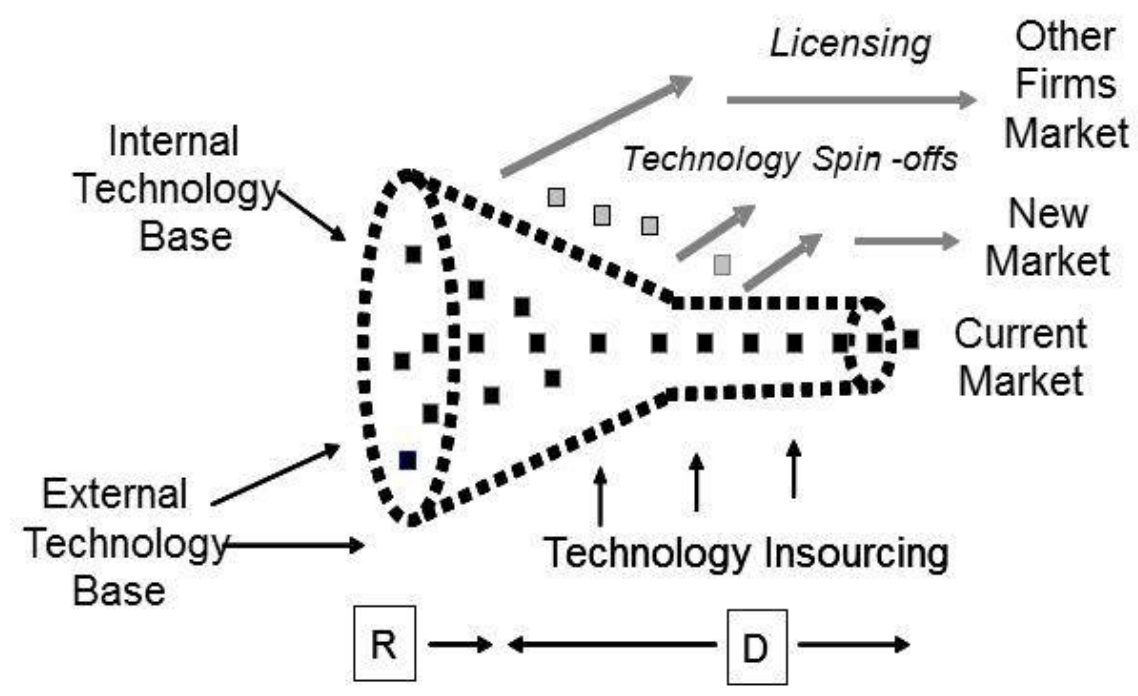

RESEARCH APPROACH: THEORY DEVELOPMENT

In research across almost every discipline, there is a diaspora of underlying theories, along with many applications, implementations and adaptations of those theories. However, before even examining the role of theory, it is important to determine what constitutes a 'good' theory, and what distinguishes it from one of lesser value. In this section, I use the five constructs proposed by Conboy (2009: 330) when he examined the development of theory in the area of Agile software methods. I apply this approach to the development of an innovation-based theory of the firm.

\section{Clarity}

One of the most fundamental attributes of a concept is that it is clearly communicated and understandable (Dubin, 1976, 1978; Metcalfe, 2004; Weick, 1989). Innovation as a concept is extremely multifaceted and is used in many different ways in the literature. Hence, there was an endeavour to define the meaning of the term innovation for the purpose of this study in the preceding sections. Inconsistency and contradiction evoke emotive descriptions, such as those levelled at, e.g. management information systems research, such as 'fragmented adhocracy' (Banville and Landry, 1989) and 'crucial but confused' (Checkland and Holwell, 1998).

\section{'Theoretical glue'}

Behind any good concept or theory, there should be a strong underlying logic and rationale. Whetten (1989) refers to this as a 'theoretical glue' that should bind all of the factors together (Conboy, 2009: 330). However, analysis of the term innovation in the preceding text revealed a multitude of underlying constructs. Consequently, providing a definition and essential rationale for the topic of innovation was seen as a fundamental task before progressing to a theory. Additionally, the framework illustrated in Figure 3 shows the theories of the firm 'bonded' in a nested Russian doll formation.

\section{Cumulative tradition}

A good concept or theory should cumulatively build on existing research (Dubin, 1978), yet this is something that, e.g. management researchers have not done particularly well (Benbasat and Zmud, 1999; Keen, 1980, 1991). Keen (1991) notes that most concepts and areas of concern in research are not as 'new' as often claimed and often 'turn out to have long roots'. The literature review on innovation herein has built the foundation of the paper on research tradition in the field and the call for more theoretical work. For example, Table 1 shows a synopsis of a tradition that developed from the seminal work of Schumpeter in the 1930s. 


\section{Parsimony}

Authoritative works on concept development usually advocate a parsimonious approach, removing any factors that provide little additional value to our understanding (Whetten, 1989). Similar to Agile research (Conboy 2009: 331), there is also much redundancy and duplication in the innovation literature together with a lot of non-value-added content. A more cohesive approach towards a theory of how innovation influences the SCA of a firm would provide a reference to help avoid duplication of effort in future research.

\section{Applicability}

The range of applications of a concept is a key criterion for judging its quality (Dubin, 1976, 1978; Metcalfe, 2004; Weick, 1989), and so any 'good' theory should be applicable in a wide variety of contexts. Theories of the firm, despite criticism and drawbacks, have exhibited a wide range of applicability to the various manifestations of the firm. The ubiquity of innovation as a conceptual framework is applicable to large multinational firms, subsidiaries, and small- and medium-sized enterprises as well as the important emerging not-for-profit sector, which is a recent and vital development in the literature of the firm.

\section{ABDUCTION}

In his 1883 work 'Theory of Probable Inference', Peirce (2010) argued that there are three fundamental kinds of reasoning: deduction, induction and abduction. Peirce was originally a Harvard chemistry graduate and his greatest philosophical influence was Kant (Hookway, 2005). Van de Ven (2007: 101) built on the work of Peirce and proposed that theory building involves three related activities:

1. Conceiving or creating a theory (abduction)

2. Constructing or elaborating the theory (deduction)

3. Justifying or evaluating a theory (induction)

Elsewhere, Scruton (2004: 190) expresses this taxonomy as follows: 'the passage down from theory to observation is one of deduction, the passage up from observation to theory is one of induction. While abduction; the term coined by C.S. Peirce to denote the process of forming a hypothesis'. Hookway (2005) describes 'the logic of abduction as the logic of discovery' as it 'studies how we are guided to a new hypothesis'. In addition, it is sometimes referred to as 'inference to the best explanation', where inference can be explained as an upgrading of belief from existing beliefs due to the gaining of new relevant information. Suppe (1999) describes abduction as the 'canons of reasoning for the discovery as opposed to the justification, of scientific hypotheses or theories'.

Van de Ven (2007: 140) describes abduction as follows:

Abduction is a creative form of reasoning that is triggered by encountering anomalies and ends by selecting a plausible or coherent solution that might resolve the anomaly.

As Svennevig (2001: 1) points out, 'practical scientific programs cannot be based on either pure deduction or pure induction. Central to any scientific process is the inferential step from some initial puzzling fact to some theoretical hypothesis which can explain it'. This is the premise on which this work is based: contemplating the recent development on the nature of the firm resulting from opening of its boundaries chiefly through the aegis of information systems has resulted in the inference of a novel hypothesis of the firm, namely IBV. Furthermore, a review of the literature and the business experience of the author have identified an anomaly in the current theories of the firm, which requires a new creative formulation of these theories.

\section{CHAMBERLIN'S MULTIPLE WORKING HYPOTHESES}

At this stage, I want to address the following question: does a new IBV of the firm usurp the previous views? To answer this, I will call on a seminal paper by Chamberlin (1890) (sic) written in the very stylised prose of that era, 
which continues to be influential. Chamberlin introduces his method of multiple working hypotheses by dividing research into two broad categories. He calls the first path 'secondary, imitative, or acquisitive study', which involves closely following the process developed by previous scholars. He describes the second category as 'primary or creative' study, where the approach is to 'think independently, or at least individually, in the endeavor to discover new truth'. Furthermore, the latter is the most promising avenue for research in subjects 'which, while much is known, more remains to be known'. Chamberlin then delineates three intellectual methods that have driven the progress of science: the method of ruling theory, the method of the working hypothesis and the method of multiple working hypotheses. He argues convincingly for the universal adoption of the last method in his paper. The dominance of 'affection for the favoured theory' causes a narrowing of vision and possibilities, which results in the stilting of research and errors such as misinterpretations and misjudgements. He expresses his concern for the ensuing detrimental research cycle: an initial precipitate explanation, which gradually evolves into a tentative theory, becomes an adopted theory and finally reaches the dubious status of the ruling theory. Evoking analogies not often found in contemporary academic literature, he points out that research - similar to love - can suffer from the tendency to blindness. Chamberlin then turns his sharp critical gaze to 'the' scientific method of his day: the working hypothesis. He concludes that while it is an improvement, its basic flaw is that it is 'but the means for the more ready development of facts and of their relations' and can quickly become the usurper to the title of the ruling theory. Chamberlin proposes that, faced with the complexities of research, the method of multiple working hypotheses provides an antidote to presumptions that this or that has been done because it accords with our ruling hypothesis or our working hypothesis'. The hypothesis of the IBV of the firm fits within Chamberlin's typology because, although much is known about the topic of innovation, much more work is required. Furthermore, IBV demonstrates 'independent thinking' and, together with RBV, KBV and dynamic capabilities, provides researchers with a toolkit of multiple working hypotheses to address the complexities of business research. These layers of theory are conceptualised in Figure 3, as presented in the 'Discussion' section. This article argues that based on the recent developments in the literature, an extension to theories of the firm from resources and knowledge to innovation, as the primary driver of competitive advantage, is now opportune. Now, I will discuss this point further.

\section{DISCUSSION}

When Cyert and March (1992) proposed their behavioural theory of the firm in 1963, they were of the opinion that the theory of the firm should be connected to what is actually happening in firms. While RBV, KBV and dynamic capabilities are cognisant of the operation of a firm, this paper argues that its recent evolution due to ICT and open innovation paradigms requires a new conceptual framework. Consequently, the incumbent theories of the firm need to be supplemented by an IBV, a perspective that is more in tune with recent developments in the literature and the realities of practice. The argument is summarised in the following proposition:

An innovation-based theory of the firm considers the ability to ethically manage and use internal and external innovation as the most strategically significant resource of the firm. The capability to manage the complexities, paradoxes and openness of innovation is an antecedent in achieving sustainable competitive advantage for a firm whether the firm is for-profit or not-for-profit.

I now discuss the definition in more detail. I argue that the present milieu that a firm is operating in precludes it from being a completely closed system. 'Open' and 'closed' modes of innovation do not comprise a digital relationship but an analogue continuum that stretches from a low degree of openness to a high degree. The term openness has been recently explored by Almirall and Casadesus-Masanell (2010) and I believe that the topic is fertile for further research.

Innovation will only be successful in a firm and a source of competitive advantage if it has the capability to manage inherent paradoxes and opposing logics. While managing paradoxes and openness can be sources of competitive advantage, resolving the dilemma of initiation and implementation is fundamental to the innovation process. This dilemma was identified in research carried out $>50$ years ago but subsequently has not been pursued in the innovation literature. My aim is to reinstate the work of Wilson (1966) and Zaltman et al. (1973) as a core component of the innovation debate. Furthermore, their theoretical studies of the 1960 and 70 s are confirmed by recent contention that the later stages of the innovation process are most difficult and time consuming (Birkinshaw et al., 2011). 
The most tangible area for innovation involves the development and introduction of products and services. However, I argue that there is a need to broaden that discussion to take into account changes in the firm's marketing strategy. There has been a significant move to delivering solutions in recent years, whereby customers have migrated from ordering products and services to ordering solutions. This has involved major firms (especially in the ICT industry) positioning themselves as solution providers where the customers describe the offering they require, while the company looks after the technicalities. Pricing is then done by functionality rather than hardware and software content. Another technological area that is affecting the milieu of the firm is servitisation (Dimache and Roche, 2013). Servitisation essentially describes the move on the Product-Service System (PSS) continuum from product-plus-service (e.g. product plus extended warranty) to complete service delivered through the product, the product being the enabler of services (e.g. delivery of cubic metres of cold air and not a refrigeration unit). In the current global economy, manufacturers are under pressure to adapt continuously to the ever-changing business environment (e.g. globalisation, environmental legislation, change in customer behaviour, trends towards purchasing services as distinct from products). Manufacturers can no longer rely on the traditional product-focused business models; they need to be highly adaptive and innovative in order to compete.

Dodgson et al. (2005) propose that a range of new technologies, such as simulation and modelling tools, virtual reality, data mining and rapid prototyping, have led to the intensification of innovation. They have used an umbrella term - innovation technology (IVT) - to describe these new tools and methods. IVT, they argue, is being increasingly applied to innovation and, indeed, is dramatically changing the nature of the innovation process. Furthermore, they contend that IVT is having a significant influence on the 'the creative tasks and the ways knowledge is constructed, shared, and used'. They describe their schema of the application of IVT to the innovation process in terms of three characteristics: thinking, playing and doing. Finally, they argue that the IvT enablement of thinking, playing and doing is a major support to organisations in dealing with disruptive innovation (doing things differently) and incremental innovation (doing existing things better).

The proposed IBV theory will be examined using the five constructs proposed by Conboy (2009) together with Peirce's concept of abduction enveloped within an ethical framework. These ideas were used as guiding principles for the development of the theory. The constructs used in this theory-building process are presented in Table 2.

Table 2. Building an IBV theory of the firm

\begin{tabular}{|c|c|}
\hline Construct & IBV theoretical framework taxonomy \\
\hline Clarity & $\begin{array}{l}\text { The term 'innovation' is multifaceted and even contentious in the voluminous and eclectic literature base. Providing an all- } \\
\text { encompassing classification of the concept is indeed a lofty undertaking. However, a definition is offered based on the author's } \\
\text { analysis of a significant number of antecedent definitions from the literature in order to clarify the term as applied to the IBV. }\end{array}$ \\
\hline $\begin{array}{l}\text { Theoretical } \\
\text { Glue }\end{array}$ & $\begin{array}{l}\text { The underlying logic and rationale for the IBV theory of the firm was compiled from a structured examination of the notion of } \\
\text { innovation vis-à-vis incumbent theories of the firm, as well as recent developments in the nature of the firm largely driven by } \\
\text { the rapid expansion of ICT. Hence, the proposed taxonomy of IBV was glued together from the exploration of the concepts of } \\
\text { innovation, theory and nature of the firm. }\end{array}$ \\
\hline $\begin{array}{l}\text { Cumulative } \\
\text { Tradition }\end{array}$ & $\begin{array}{l}\text { The cumulative tradition of scholarship on innovation, from its origins in the work of Schumpeter and developed over the past } \\
\text { number of decades, was synthesised in the literature review and an attempt was made to summarise its evolution in Table } 1 . \\
\text { However, the author is conscious of the justifiable criticism of such an undertaking considering the volume of studies. Also, IBV } \\
\text { was placed in the development of the managerial theories of the firm originating from scholars such as Edith Penrose. }\end{array}$ \\
\hline Parsimony & $\begin{array}{l}\text { The definition of innovation was developed from an investigation and parsing of many antecedent definitions. There was } \\
\text { much duplication and redundancy in the resulting spreadsheet containing the main concepts uncovered during the analysis. } \\
\text { Consequently, the IBV proposed in the study is a concise formulation that facilitates future investigation and empirical studies. }\end{array}$ \\
\hline Applicability & $\begin{array}{l}\text { This study argued that developments in ICT and the nature of the firm have resulted in the incumbent theories of the firm having } \\
\text { limited applicability in the current business landscape. As a result, the encompassing nature of the concept of innovation has } \\
\text { ensured that IBV is valid in the broad spectrum of business situations. An additional novelty in IBV is the inclusion of the emerging } \\
\text { not-for-profit sector. }\end{array}$ \\
\hline Abduction & $\begin{array}{l}\text { It is argued that the paper makes an academic contribution by providing an example of the initiating theory using abduction } \\
\text { (conceiving of theory), which has recently been brought to the forefront of management research by Andrew Van de Ven. } \\
\text { Antecedent theories of the firm were largely developed, analysed and researched using the traditional concepts of induction and } \\
\text { deduction. }\end{array}$ \\
\hline Eth & $\begin{array}{l}\text { Ethics is a fundamental area of philosophical inquiry and of managerial practice. The inclusion of ethics in the IBV definition was } \\
\text { a response to the virtual absence of any reference to this topic in the analysis of the innovation definitions in the literature. It is } \\
\text { proposed that this approach in the current study is an important contribution to the investigation of the nature of a firm. }\end{array}$ \\
\hline
\end{tabular}


Now, I summarise my argument that an IBV does not replace RBV, KBV and dynamic capabilities, but that they form an integral holistic lens to examine the nature of the firm. This conceptualisation is proposed in Figure 3. Note that the dashed outer line is used to signify the permeability of the firm's boundaries driven by ICT and the increasing emphasis on 'open innovation'.

The implications of an innovation-based theory of the firm is outlined in the next section.

Figure 3. Managerial theories of the firm as nested extensions.

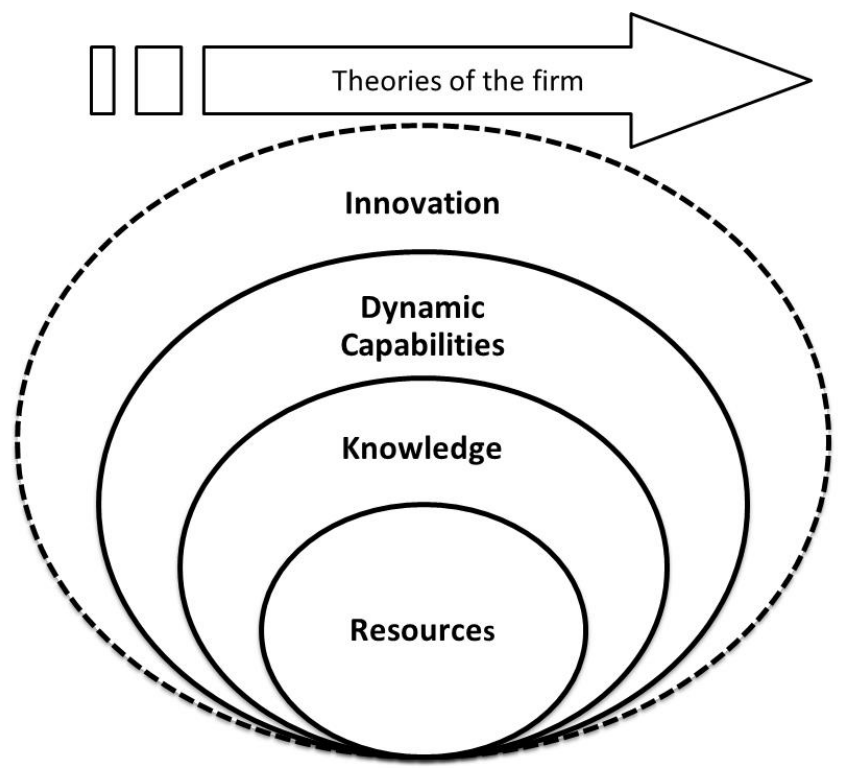

\section{Implications and limitations of the study}

There has been a renewed call for 'good concepts and theories' to stimulate research and counteract a perceived 'ambivalent attitude towards theory' in the management fields (Markus and Saunders, 2007). Testing out the IBV hypothesis in the field will be a challenge for future work. Neavel-Dickens (1998: 257) states that 'it will be important to include more practitioner voices in studies of action research'. The initial fieldwork and research that preceded this paper consisted of a 2-year longitudinal study of innovation in a multinational subsidiary. As a result, IBV has implications for decision-makers on the assessment of a firm and its subsidiaries, as it implies that more emphasis should be given to the significance of innovation vis-à-vis the current prominence of purely economic key performance indicators (KPI). Consequently, it will challenge practitioners to develop a more long-term and holistic view of a firm's contribution. The details of implementing such a perspective are suitable for further work. It is also argued that the method can facilitate the further generation of theory as presented in this study. In this regard, the seminal Minnesota Innovation Research Program (MIRP) concluded that further theoretical development is required to incorporate local and global phenomena 'at different levels of analysis, such as how individuals relate to project teams, teams to organisations, organisations to a larger industry community' (Van de Ven et al., 2000: 641). Moreover, Storey (2004), in his review of key articles from $>30$ years of research, emphasises the growing prevalence of alliances and interorganisational networks, with their increasing importance for innovation. A prominent theme emerging from studies in the area is the subject of social relationships, which includes factors such as 'persuasion, influence, politics and power' ( $p$. xxviii). The inclusion of ethics in the theory building and IBV definition was a response to the virtual absence of any reference to this fundamental philosophical topic in the analysis of the innovation definitions in the literature. Engagement of researchers with the work of philosophers such as Lévinas (1998), Davis (1996) and Alasdair MacIntyre (2002) would be a fruitful step in this direction.

The paper is limited in that the approach of abduction involves the conceiving theory and, as such, is open to the criticisms inherent in such an endeavour. More work is required to examine what IBV entails and to provide a more comprehensive explanation of its consequences. However, I consider that this initial paper was required to set out the landscape that needs further exploration. 


\section{CONCLUSIONS}

According to Damanpour et al. (2009), innovation is a primary source of economic growth, industrial change and competitive advantage. Management innovation is an area ripe for research stimuli, which, I argue, must be underpinned by a strong theoretical basis. KBV, RBV and dynamic capabilities are influential theories of the firm used in business and management research. The review has indicated that a growing body of literature points to innovation as the principal source of competitive advantage. In addition, the emerging models of 'open innovation' posit that knowledge and resources increasingly reside outside the firm's locus of control. Innovation is putting knowledge into action and has a link to absorptive capacity (Tsai, 2004). It is more than just acquiring knowledge. Viewing the firm now must be carried out by a two-headed Janus, looking inward and outward. Furthermore, the paper makes a significant academic contribution by providing an example of initiating theory using abduction. Consequently, an IBV of the firm is proposed as a novel contribution to theory. Using the influential paper of Thomas Chamberlin as a starting point, the theory has been developed using abduction as originally proposed by Peirce and more recently presented to the management discipline by Van de Ven. Such underpinning is required to advance a strong research agenda, particularly in nascent areas such as management innovation, which is beginning to receive attention from scholars (Mol and Birkinshaw, 2009). Future work is required to develop the insights of this paper using deductive logic and, following this, testing of the theory using induction. In his seminal paper, Wernerfelt (1984: 180) commented that his paper was meant 'only as a first cut at a huge can of worms'. I hope that this paper can stimulate some debate on the contemporary nature of the firm as well as competitive advantage.

\section{ACKNOWLEDGEMENTS}

The author thanks the following for their support and advice in the development of this paper: Kieran Conboy, Brian Donnellan, Willie Golden and Eoin Whelan.

\section{References}

Allen, T.J. (2004). 'Communication networks in R\&D laboratories,' in R. Katz (ed), The Human Side of Managing Technological Innovation: A Collection of Readings, 2nd ed, Oxford: Oxford University Press.

Almirall, E. and Casadesus-Masanell, R. (2010). 'Open versus closed innovation: A model of discovery and divergence'. Academy of Management Review, 35: 27-47.

Angle, H.L. and Van De Ven, A.H. (2000). 'Suggestions for managing the innovation journey', in A.H. Van De Ven, H.L. Angle and M.S. Poole (eds), Research on the Management of Innovation: The Minnesota Studies (First Published 1989), Oxford; New York: Oxford University Press.

Banville, C. and Landry, M. (1989). 'Can the field of MIS be disciplined'? Communication of the ACM, 32: 48-60.

Barney, J.B. (1991). 'Firm resources and sustained competitive advantage'. Journal of Management Information Systems, 17: 99-120.

Basadur, M. and Gelade, G.A. (2006). 'The role of knowledge management in the innovation process'. Creativity and Innovation Management, 15: 45-62.
Becerra, M. (2009). Theory of the Firm for Strategic Management: Economic Value Analysis, Cambridge: Cambridge University Press.

Benbasat, I. and Zmud, R. (1999). 'Empirical research in information systems: The practice of relevance'. Mis Quarterly, 23: 3-16.

Birkinshaw, J., Bouquet, C. and Barsoux, J.-L. (2011). 'The 5 myths of innovation'. Sloan Management Review, 52: 43-50.

Brynjolfsson, E. and Saunders, A. (2009). Wired for Innovation: How Information Technology Is Reshaping the Economy, Cambridge, MA: MIT Press.

Chamberlin, T.C. (1890). 'The method of multiple working hypotheses.' Science, 15.

Checkland, P. and Holwell, S. (1998). Information Systems and Information Systems, Chichester: John Wiley and Sons.

Chesbrough, H.W. (2003). Open Innovation: The New Imperative for Creating and Profiting from Technology, Boston: Harvard Business School.

Chesbrough, H.W. (2006). 'Open innovation: A new paradigm for understanding industrial innovation', in $\mathrm{H}$. Chesbrough, W. Vanhaverbeke and J. West 
(eds), Open Innovation: Researching a New Paradigm, Oxford: Oxford University Press.

Christensen, C.M., Yang, W., Verlinden, M.C. and King, S.M. (2005). Chip industry must learn not to overshoot. EE Times. http://www.eetimes.com/ document.asp?doc_id=1154483 [Accessed May 2015].

Coakes, E. (2000). 'Knowledge management: A sociotechnical perspective', in E. Coakes, D. Willis and S. Clarke (eds), Knowledge Management in the Sociotechnical World: The Graffiti Continues, London: Springer.

Colarelli-O'CONNOR, G. (2008). 'Major innovation as a dynamic capability: A systems approach'. Journal of Product Innovation Management, 25: 313-330.

Conboy, K. (2009). 'Agility from first principles: Reconstructing the concept of agility in information systems development'. Information Systems Research, 20: 329-354.

Costello, G.J. and Donnellan, B. (2007). 'The diffusion of WOZ: Expanding the topology of IS innovations', Journal of Information Technology, 22: 79-86. doi:10.1057/palgrave.jit.2000085.

Costello, G.J. and Donnellan, B. (2008). 'Seeking the face of innovation with the ethical compass of Emmanuel Levinas', in G. León, A. Bernardos, J. Casar, K. Kautz, and J. Degross, (eds.) IFIP International Federation for Information Processing, Volume 287, Open IT-Based Innovation: Moving Towards Cooperative IT Transfer and Knowledge Diffusion, Boston: Springer.

Cyert, R.M. and March, J.G. (1992). A Behavioral Theory of the Firm, Oxford: Blackwell Business.

Damanpour, F., Walker, R.M. and Avellaneda, C.N. (2009). 'Combinative effects of innovation types and organizational performance: A longitudinal study of service organizations'. Journal of Management Studies, 46: 650-675 doi: 10.1111/j.14676486.2008.00814.x.

Davis, C. (1996). Levinas: An Introduction, Cambridge, UK: Polity Press.

Dimache, A. and Roche, T. (2013). 'A decision methodology to support servitisation of manufacturing'. International Journal of Operations \& Production Management, 33.

Dodgson, M., Gann, D. and Salter, A. (2005). Think, Play, Do: Technology, Innovation, and Organization, Oxford: Oxford University Press.

Douma, S. and Schreuder, H. (2008). Economic Approaches to Organizations, 4th edn, New Jersey: Prentice Hall

Drucker, P. (1985). Innovation and Entrepreneurship: Practice and Principles, London: Heinemann.
Drucker, P. (1988). The Coming of the New Organization, Cambridge MA: Harvard Business School Press.

Dubin, R. (1976). 'Theory building in applied areas', in M. Dunnette (ed) Handbook of Industrial and Organisational Psychology, Chicago: Rand McNally.

Dubin, R. (1978). Theory Development, New York: Free Press.

Eppinger, S.D. (2001). 'Innovation at the speed of information'. Harvard Business Review, 79: 149158.

Fagerberg, J. (2005). 'Innovation: A guide to the literature', in J. Fagerberg, D. Mowery and R.R. Nelson (eds), The Oxford Handbook of Innovation, Oxford: Oxford University Press.

Goffin, K. and Mitchell, R. (2005). Innovation Management: Strategy and Implementation Using the Pentathlon Framework, Houndmills, Basingstoke: Palgrave Macmillan.

Grant, R.M. (1996). 'Toward a knowledge-based theory of the firm'. Strategic Management Journal, 17: 109-122.

Helfat, C.E. and Peteraf, M.A. (2009). 'Understanding dynamic capabilities: progress along a developmental path'. Strategic Organization 7: 91102.

Hookway, C.J. (2005). 'Peirce, Charles Sanders', in T. Honderich (ed), The Oxford Companion to Philosophy, 2nd edn, Oxford: Oxford University Press.

Hoskisson, R.E., Hitt, M.A., Wan, W.P. and Yiu, D. (1999). 'Theory and research in strategic management: Swings of a pendulum'. Journal of Management, 25: 417-456.

Katz, R. (2004). 'Introduction', in R. Katz (ed), The Human Side of Managing Technological Innovation: A Collection of Readings, 2nd edn, Oxford: Oxford University Press.

Keen, P. (1980). 'Mis research: Reference disciplines and a cumulative tradition'. in E. Mclean (ed), Proceedings of the First International Conference on Information Systems, Philadelphia, 9-18.

Keen, P. (1991). 'Relevance and rigor in information systems research: Improving quality, confidence cohesion and impact', in H. Nissen, H. Klein and R. Hirschheim (eds), Information Systems Research: Contemporary Approaches and Emergent Traditions, Amsterdam: North-Holland.

Klein, P.G., Mahoney, J.T., Mcgahan, A.M. and Pitelis, C.N. (2010). 'Toward a theory of public entrepreneurship'. European Management Review, 7: 1-15.

Kraaijenbrink, J., Spender, J.-C. and Groen, A. J. 
(2010). 'The resource-based view: A review and assessment of its critiques'. Journal of Management, 36: 349-372.

Laudon, K.C. and Laudon, J.P. (2002). Management Information Systems: Managing the Digital Firm, New Jersey: Prentice Hall.

Lazonick, W. (2005). 'The Innovative Firm', in J. Fagerberg, D. Mowery, and R.R. Nelson (eds), The Oxford Handbook of Innovation, Oxford: Oxford University Press.

Leonard, D. (1998). Wellsprings of Knowledge: Building and Sustaining the Sources of Innovation, Brighton, MA: Harvard Business School Press.

Lévinas, E. (1998). Otherwise Than Being, or, Beyond Essence, Pittsburgh, PA: Duquesne University Press.

Macintyre, A.C. (2002). A Short History of Ethics: A History of Moral Philosophy from the Homeric Age to the 20th Century, London: Taylor \& Francis Ltd.

Markus, M.L. and Saunders, C. (2007). 'Looking for a few good concepts ... and theories ... for the information systems field'. MIS Quarterly, 31: iii-vi.

Mcinerney, D.P.A. (2004). Innovative Regions: A Comparative Analysis of the Innovative Activities of Indigenous and Non-Indigenous Small and Medium Sized Enterprises (SMEs) in the Shannon and Dublin Regions of Ireland, PhD Thesis. University of Limerick, Ireland.

Metcalfe, M. (2004). 'Theory: seeking a plain English explanation'. Journal of Information Technology Theory and Application, 6: 13-21.

Mol, M.J. and Birkinshaw, J. (2009). 'The sources of management innovation: When firms introduce new management practices'. Journal of Business Research 62: 1269-1280.

Neavel Dickens, L. (1998). A Theory of Action Perspective of Action Research, PhD Dissertation. University of Texas at Austin.

O'Brien, J.A. and Marakas, G.M. (2009). Management Information Systems, Boston: McGraw-Hill Irwin.

OECD (2005). Oslo Manual: Guidelines for Collecting and Interpreting Innovation Data, 3rd edn, Paris: Organisation for Economic Co-Operation and Development, Directorate for Science, Technology and Industry.

Peirce, C.S. (2010). Writings of Charles S. Peirce: A chronological edition. Volume 8, 1890-1892/Edited by the Peirce Edition Project, Bloomington, IN: University Press.

Penrose, E. (2009). The Theory of the Growth of the Firm with a New Introduction by Christos N. Pitelis, Oxford; New York: Oxford University Press.

Peteraf, M.A. (1993). 'The cornerstones of competitive advantage: A resource-based view'. Strategic Management Journal, 14.

Pettigrew, A.M. (1987). 'Introduction: Researching strategic change', in A.M. Pettigrew (ed.), The Management of Strategic Change, Oxford: Basil Blackwell.

Pfaffenberger, B. (2002). Computers in Your Future, Upper Saddle River, NJ: Prentice Hall.

Pitelis, C.N. and Teece, D.J. (2009). 'The (new) nature and essence of the firm'. European Management Review, 6: 5-15. doi: 10.1057/emr.2009.1.

Poole, M.S. and Van De Ven, A.H. (2000). 'Towards a general theory of innovation processes', in A.H. Van De Ven, H.L. Angle and M.S. Poole (eds.), Research on the Management of Innovation: The Minnesota Studies. Oxford; New York: Oxford University Press.

Post, G.V. and Anderson, D.L. (2003). Management Information Systems: Solving Business Problems with Information Technology, Boston; London, McGraw-Hill/Irwin.

Pullen, A., Petra C. De Weerd-Nederhof, Groen, A.J. and Fisscher, O.A.M. (2012). 'Open innovation in practice: Goal complementarity and closed Npd networks to explain differences in innovation performance for SMEs in the medical devices sector'. Journal of Product Innovation Management, 29: 917-934.

Rahmanseresht, H. (1988). 'Towards a revised model of innovation in organisations', PhD Thesis. University of Hull.

Robson, W. (1997). Strategic Management and Information Systems: An Integrated Approach, London: Pitman Publishing.

Rogers, E.M. and Shoemaker, F.F. (1971). Communication of Innovations: A Cross-Cultural Approach, New York, NY: The Free Press.

Rothwell, R. (1994). 'Towards the fifth-generation innovation process'. International Marketing Review, 11: 7-31.

Sautet, F. (2000). Entrepreneurial Theory of the Firm, London: Routledge.

Schumpeter, J.A. (1934). The Theory of Economic Development: An Inquiry into Profits, Capital, Credit, Interest, and the Business Cycle, Cambridge, MA: Harvard University Press (1959 printing).

Scruton, R. (2004). Modern Philosophy: An Introduction and Survey, London: Pimlico.

Slappendel, C. (1996). 'Perspectives on innovation in organizations'. Organization Studies, 17: 107-129.

Spender, J.C. (1996). 'Making knowledge the basis of a dynamic theory of the firm'. Strategic Management Journal, 17: 45-62. 
Storey, J. (2004). The Management of Innovation: Volume I, Cheltenham, UK: Northampton Edward Elgar.

Suppe, F. (1999). 'Abduction', in: R. Audi (ed.), The Cambridge Dictionary of Philosophy, New York: Cambridge University Press.

Svennevig, J. (2001). 'Abduction as a methodological approach to the study of spoken interaction'. Norskrift, 103: 1-22.

Swanson, E.B. (1994). 'Information systems innovation among organizations'. Management Science, 40: 1069-1092.

Swedberg, R. (1991). Joseph A. Schumpeter: His Life and Work, Cambridge: Polity Press.

Teece, D.J., Pisano, G. and Shuen, A. (1997). 'Dynamic capabilities and strategic management'. Strategic Management Journal, 18: 509-533.

Tsai, W. (2004). 'Knowledge transfer in intraorganizational networks: Effects of network position and absorptive capacity on business unit innovation and performance, 2001, Academy of Management Journal, 44: 996-1004', in J. Storey (ed.), The Management of Innovation: Volume II. Cheltenham, UK: Northampton Edward Elgar.

Van De Ven, A.H. (1986). 'Central problems in the management of innovation'. Management Science, 32: 590-607.

Van De Ven, A.H. (ed.) (2007). Engaged Scholarship: A Guide for Organizational and Social Research, Oxford; New York: Oxford University Press.

Van De Ven, A.H., Angle, H.L. and Poole, M.S. (eds.) (2000). Research on the Management of Innovation: The Minnesota Studies, Oxford; New York: Oxford University Press.

Vanhaverbeke, W. and Cloodt, M. (2006). 'Open innovation in value networks', in $\mathrm{H}$. Chesbrough, W. Vanhaverbeke and J. West (eds.) Open Innovation: Researching a New Paradigm. Oxford; New York: Oxford University Press.

Volberda, H.W., Bosch, F.A.J.V.D. and Heij, C.V. (2013). 'Management innovation: management as fertile ground for innovation'. European Management Review, 10: 1-15. doi: 10.1111/emre.12007.

Von Hippel, E. (2005). Democratizing Innovation, Massachusetts: The MIT Press.

Von Hippel, E. and Von Krogh, G. (2003). 'Open source software and the "Private-Collective" innovation model: issues for organization science'.
Organization Science, 14: 209-223.

Walton, R.E. (1987). Innovating to Compete, San Francisco: Jossey-Bass.

Ward, J., Griffiths, P. and Whitmore, P. (1990). Strategic Planning for Information Systems, Chichester: John Wiley \& Sons.

Wasko, M.M. and Faraj, S. (2005). 'Why should I share? Examining social capital and knowledge contribution in electronic networks of practice'. Mis Quarterly, 29: 35-57.

Webster, J. and Watson, R.T. (2002). 'Analyzing the past to prepare for the future: writing a literature review'. Mis Quarterly, 26: xiii-xxiii.

Weick, K. (1989). 'Theory construction as disciplined imagination'. Academy of Management Review, 14: 516-531.

Wernerfelt, B. (1984). 'A resource-based view of the firm'. Strategic Management Journal, 5: 99-197.

West, J., Vanhaverbeke, W. and Chesbrough, $\mathrm{H}$. (2006). 'Open innovation: a research agenda', in $\mathrm{H}$. Chesbrough, W. Vanhaverbeke and J. West (eds.) Open Innovation: Researching a New Paradigm, Oxford; New York: Oxford University Press.

Whelan, E., Parise, S., Valk, J.D. and Aalbers, R. (2011). 'Creating employee networks that deliver open innovation'. Mit Sloan Management Review, 53: $37-45$

Whetten, D.A. (1989). 'What constitutes a theoretical contribution'? Academy of Management Review, 14: 490-495.

Wilson, J.Q. (1966). 'Innovation in organizations: notes toward a theory', in J.D. Thompson (ed.), Approaches to Organizational Design, Pittsburgh, PA: University of Pittsburgh Press.

Wolfe, R.A. (1994). 'Organizational innovation: review, critique and suggested research directions'. Journal of Management Studies, 31: 405-431.

Yin, R., Heald, K. and Vogel, M. (1977). Tinkering with the System: Technological Innovations in State and Local Services, Toronto: Lexington Books.

Zain, M. (1993). 'A field study of adoption and implementations of innovations by manufacturing firms in Malaysia', PhD Thesis. Manchester Business School.

Zaltman, G., Duncan, R. and Holbek, J. (1973). Innovations and Organizations, New York: Wiley. 